\title{
PERBEDAAN KECEMASAN KELUARGA PASIEN GANGGUAN JIWA SAAT PASIEN RAWAT INAP DAN MENJELANG PULANG DI RSUD BANYUMAS
}

\author{
Gun Adi Komara ${ }^{1}$ Keksi Girindra Swasti ${ }^{2}$ Wahyu Ekowati ${ }^{3}$
}

\begin{abstract}
ABSTRAK
Latar belakang: Gangguan jiwa merupakan penyakit mental dimana keluarga memiliki peranan yang besar pada proses penyembuhan. Namun ketika pasien melakukan perawatan, keluarga dapat mengalami masalah seperti kecemasan. Kecemasan terjadi pada keluarga saat pasien menjalani rawat inap dan saat pasien menjelang pulang dari Instalasi Pelayanan Kesehatan Jiwa Terpadu.

Tujuan: Penelitian ini bertujuan untuk mengidentifikasi perbedaan skor kecemasan keluarga saat pasien gangguan jiwa menjalani rawat inap dengan saat pasien menjelang pulang dari Instalasi Pelayanan Kesehatan Jiwa Terpadu.

Metode: Penelitian ini menggunakan rancangan cross sectional. Pengambilan sampel menggunakan consecutive sampling dalam periode 30 Maret-30 April 2015 di RSUD Banyumas dan diperoleh 32 keluarga. Instrumen penelitian ini menggunakan kuesioner HARS yang telah dimodifikasi. Analisis data menggunakan uji t berpasangan.

Hasil: Rerata skor kecemasan keluarga saat pasien menjalani rawat inap adalah 20, sedangkan rerata skor kecemasan keluarga saat pasien menjelang pulang adalah 15,18 . Hasil uji t berpasangan antara skor kecemasan keluarga saat pasien menjalani rawat inap dan menjelang pulang diperoleh nilai $\mathrm{p}=0,000(\mathrm{p}<0,05)$.

Kesimpulan: Ada perbedaan skor kecemasan keluarga pasien gangguan jiwa, dimana skor kecemasan keluarga saat pasien gangguan jiwa menjalani rawat inap lebih besar dibandingkan dengan skor kecemasan keluarga saat pasien menjelang pulang dari Instalasi Pelayanan Kesehatan Jiwa Terpadu.
\end{abstract}

Kata Kunci : gangguan jiwa, kecemasan, keluarga

\begin{abstract}
ABSTRAC
Background: Mental disorder is a mental illness which families have a significant role in the healing process. However when patient care, the family has problems such as anxiety. Anxiety occurs in families when the patient is hospitalized and patient ahead to home from Installation of Integrated Mental Health Service .

Objective: This study aimed to identify differences in anxiety scores when mental disorder patient hospitalized with when patient ahead to home from Installation of Integrated Mental Health Service.

Methods: The study used a non-experimental with cross sectional design. Sampling using consecutive sampling during the period March 30 until April 30, 2015 in Banyumas General Hospital gained 32 families. The instrument of this study using a HARS questionnaires has been modified. Analysis of data using paired t test.

Result: The average anxiety score family patient's when patients hospitalized was 20, While the average family anxiety score ahead to home 15,18. The result using paired t-test between family anxiety scores when patients hospitalized and ahead to home obtained by the value of $p=0.000$ ( $p$ $<0.05)$.

Conclusion: There is a difference in the score anxiety the patient's family of a mental disorder, where a score of family anxiety when patients hospitalized larger than the score when family anxiety patients ahead to home from Installation Of Integrated Mental Health Services.
\end{abstract}

Keyword: mental disorders, anxiety, family 


\section{LATAR BELAKANG}

American Psychiatric Association (2000) dalam Diagnostic and statistical manual of mental disorder IV (DSM-IV) mendefinisikan gangguan jiwa sebagai sindrom psikologi yang bermakna secara klinis. Seseorang yang mengalami gangguan jiwa memiliki pola perilaku yang berhubungan dengan distress (gejala yang menyakitkan) dan disability (penurunan fungsi pada daerah atau organ yang penting).

\section{Data World Health Organization} (WHO) tahun 2000 menunjukkan ada sekitar 450 juta orang di seluruh dunia yang mengalami gangguan jiwa (Ghanem, Gadallah, Meky, Mourad, \& El Kholy, 2009). Data Riset Kesehatan Dasar (Riskesdas) tahun 2013 diketahui bahwa prevalensi gangguan jiwa secara nasional sebesar 6\% atau 1,7 kasus gangguan jiwa per mil.

Penderita gangguan jiwa dapat memanfaatkan beberapa fasilitas kesehatan untuk proses pengobatan. Berdasarkan penelitian Kessler et al. (2005) pelayanan kesehatan umum (rumah sakit) menjadi penanganan yang paling sering dikunjungi terkait gangguan jiwa.

Pasien gangguan jiwa yang ditangani oleh rumah sakit akan mendapatkan beberapa terapi. Terapi tersebut diantaranya adalah terapi psikofarmaka, terapi kelompok, terapi psikoreligius, dan terapi modalitas (Yosep, 2011). Salah satu terapi yang memiliki risiko paling serius adalah terapi ECT yang dapat menimbulkan dampak hingga kematian (Andrade $e t$ al. 2012). Selain dari tindakantindakan pengobatan yang berisiko mengancam jiwa seperti terapi ECT, sumber kecemasan keluarga lainnya adalah ketidakpastian kesembuhan anggota keluarga yang mendapat penanganan di rumah sakit, masalah keuangan, perubahan peran, gangguan rutinitas dan lingkungan rumah sakit yang asing (Leske, 2002).

Kondisi selanjutnya adalah ketika pasien gangguan jiwa selesai mendapatkan penanganan di rumah sakit (menjelang pasien pulang). Kondisi ini berbeda dengan pasien dengan masalah fisik. Pada pasien dengan masalah fisik, keluarga akan 
merasakan ketenangan ketika pasien sudah diperbolehkan pulang oleh tenaga kesehatan, sementara bagi keluarga pasien gangguan jiwa akan mengalami kekhawatiran ketika pasien selesai menjalani pengobatan akibat seringnya riwayat kekambuhan. Sebuah penelitian yang dilakukan oleh Amalia (2009) menunjukkan bahwa terdapat kecemasan atau kekhawatiran pada keluarga pasien gangguan jiwa saat pasien menjelang pulang. Hal ini diperkuat oleh penelitian Wuryaningsih, Hamid, dan Helena (2013) yang menyebutkan sebagian besar pasien gangguan jiwa berat yang memiliki riwayat rawat inap akan berisiko untuk kembali melakukan rawat inap (rehospitalisasi) akibat kekambuhan pasien.

Berdasarkan penelitian Amalia (2009) diketahui bahwa kesiapan dan kecemasan pada keluarga dalam menghadapi kepulangan pasien dipengaruhi oleh faktor internal dan eksternal. Kecemasan keluarga semakin bertambah dengan adanya komplikasi dari proses perawatan di rumah sakit. Hal ini sesuai dengan penelitian yang dilakukan oleh Hellström, Eplov, Nordentoft, Ostergaard, dan Bech (2014) yang menunjukkan bahwa proses penanganan di rumah sakit akan mengakibatkan pasien mengalami afasia.

Rumah Sakit Umum Daerah (RSUD) Banyumas merupakan rumah sakit yang mempunyai Instalasi Pelayanan Kesehatan Jiwa Terpadu, baik pelayanan berupa rawat inap ataupun rawat jalan. Ruang Arjuna dan Bima adalah ruang rawat inap yang didampingi oleh keluarga. Pada ruang tersebut tentu sangat berisiko bagi keluarga pasien gangguan jiwa menghadapi berbagai kendala atau masalah khususnya adalah kecemasan.

Hasil studi pendahuluan melalui wawancara dengan dua keluarga pasien gangguan jiwa didapatkan bahwa, keluarga mengalami kecemasan ketika mendampingi pasien rawat inap dan menjelang pulang dari RS. Kecemasan keluarga saat mendampingi pasien tersebut terkait masa depan pasien gangguan jiwa akibat lamanya rawat inap yang 
dijalani dan adanya masalah ekonomi yang dialami oleh keluarga yang disebabkan pasien merupakan kepala keluarga sebagai sumber penghasilan dalam keluarga tersebut. Sementara kecemasan keluarga saat pasien menjelang pulang terlihat ketika keluarga mengatakan adanya kekhawatiran yang mendalam akibat seringnya pasien keluar masuk RS dan riwayat kekambuhan ketika pasien berada di rumah. Kedua kondisi tersebut sama-sama mengakibatkan kecemasan namun belum diketahui mana kondisi yang menimbulkan kecemasan lebih tinggi.

Oleh karena itu perlu dilakukan penelitian untuk membedakan kecemasan agar menjadi dasar dalam penanganan pada kedua kondisi tersebut.

\section{METODE PENELITIAN}

Penelitian ini merupakan penelitian kuantitatif dengan desain cross sectional. Penelitian dilaksanakan tanggal 30 Maret sampai 30 April 2015. Teknik pengambilan sampel dengan cara consecutive sampling. Instrument penelitian berupa kuesioner kecemasan Hamilton Anxiety Rating Scale (HARS) yang telah dimodifikasi. Analisis data menggunakan uji $\mathrm{t}$ berpasangan (paired sample t test).

\section{HASIL PENELITIAN}

Hasil pada penelitian ini disajikan dalam bentuk tabel distribusi frekuensi dan tendensi sentral.

Tabel 1. Distribusi frekuensi responden keluarga pasien gangguan jiwa di Instalasi Pelayanan Kesehatan Jiwa Terpadu RSUD Banyumas $(n=32)$ 


\begin{tabular}{llcc}
\hline Variabel & Kategori & Frekuensi (n) & Persentase (\%) \\
\hline Usia & Dewasa awal (18-40) & 13 & 40,6 \\
& Dewasa madya (41-60) & 17 & 53,1 \\
& Dewasa akhir (>60) & 2 & 6,3 \\
\hline Jenis kelamin & Perempuan & 21 & 65,6 \\
& Laki-laki & 11 & 34,4 \\
\hline Tingkat & Tidak sekolah & 1 & 3,1 \\
pendidikan & SD & 16 & 50 \\
& SMP & 11 & 34,4 \\
& SMA & 3 & 9,4 \\
& Perguruan tinggi & 1 & 3,1 \\
\hline Penghasilan & $\leq 1000000$ & 25 & 78,1 \\
& $>1000000$ & 7 & 21,9 \\
\hline Hubungan & Orang tua & 16 & 50 \\
dengan pasien & Saudara kandung & 8 & 25 \\
& Lain-lain & 8 & 25 \\
\hline
\end{tabular}

Berdasarkan Tabel 1 diketahui bahwa responden berjumlah 32 orang. Mayoritas responden berada pada usia dewasa madya (41-60) sejumlah 17 orang atau $53,1 \%$ dan berjenis kelamin perempuan berjumlah 21 orang atau $65,6 \%$. Responden penelitian sebagian besar menempuh pendidikan akhir pada tingkat pendidikan Sekolah Dasar (SD) berjumlah 16 orang atau 50\% dan penghasilan $\leq 1000000$ berjumlah 25 atau $78,1 \%$. Mayoritas responden adalah orang tua dari pasien, sejumlah 16 responden atau $50 \%$.

Tabel 2. Rerata skor kecemasan keluarga pasien gangguan jiwa di Instalasi Pelayanan Kesehatan Jiwa Terpadu RSUD Banyumas $(n=32)$

\begin{tabular}{lcc}
\hline \multicolumn{1}{c}{ Variabel } & Mean & SD \\
\hline Saat mendampingi pasien menjalani perawatan & 20 & 9.685 \\
\hline Saat pasien menjelang pulang & 15,187 & 6,402 \\
\hline
\end{tabular}

Berdasarkan tabel 2 diketahui bahwa responden memiliki rata-rata skor kecemasan saat mendampingi pasien menjalani rawat inap di instalasi jiwa adalah 20 dengan standar deviasi sekitar 9,685. Skor tersebut berada pada kategori kecemasan sedang (18-
24), sementara rata-rata skor kecemasan responden ketika pasien menjelang pulang dari Instalasi Pelayanan Kesehatan Jiwa Terpadu adalah 15,187 dengan standar deviasi 6,402 dan berada pada kategori kecemasan ringan $(<17)$. 
Tabel 3. Perbedaaan skor kecemasan keluarga saat mendampingi pasien gangguan jiwa menjalani rawat inap dan menjelang pulang dari Instalasi Pelayanan Kesehatan Jiwa Terpadu RSUD Banyumas $(n=32)$

\begin{tabular}{lccccc}
\hline \multicolumn{1}{c}{ Variabel } & $\mathrm{N}$ & Rerata $\pm \mathrm{sb}$ & $\begin{array}{c}\text { Perbedaan } \\
\text { Rerata } \pm \mathrm{sb}\end{array}$ & IK95\% & $\mathrm{p}$ \\
\hline $\begin{array}{l}\text { Skor kecemasan keluarga } \\
\text { pasien saat menjalani } \\
\text { rawat inap }\end{array}$ & 32 & $20 \pm 9,685$ & $13,93 \pm 6,28$ & $\begin{array}{c}11,66- \\
16,20\end{array}$ & 0,000 \\
$\begin{array}{l}\text { Skor kecemasan keluarga } \\
\text { pasien gangguan jiwa } \\
\text { saat menjelang pulang }\end{array}$ & 32 & $15,18 \pm 6,402$ & & & \\
\hline
\end{tabular}

Data dianalisis dengan menggunakan uji statistik paried sample $t$ test dengan tingkat kepercayaan $95 \%(\alpha=$ 0,05). Sebelum dilakukan uji tersebut data telah di uji normalitas dan diperoleh hasil salah satu data tidak normal, kemudian dilakukan tranformasi data dengan log 10 (Dahlan, 2010) sehingga data keseluruhan menjadi normal. Setelah data normal dilakukan uji statistik paried sample $t$ test dan hasil didapatkan nilai $\mathrm{p}$ value adalah 0,000 , dengan demikian $\mathrm{p}$ value $<\alpha$, sehingga Ha diterima.

Dapat disimpulkan bahwa ada beda skor kecemasan keluarga saat mendampingi pasien gangguan jiwa dengan skor kecemasan keluarga menjelang pasien pulang dari Instalasi Pelayanan Kesehatan Jiwa Terpadu RSUD Banyumas.

\section{PEMBAHASAN}

\section{Profil demografi}

Berdasarkan penelitian ini responden sebagian besar adalah dewasa madya. Seseorang dengan dewasa madya memiliki karakteristik seperti berubahnya berbagai perilaku dengan menunjukkan adanya kejenuhan pada pekerjaannya dan lebih memilih berkumpul serta beraktivitas dengan keluarga, selain itu dewasa madya juga berusaha untuk mencari pengalaman baru (Wicaksana, 2008). Pernyataan tersebut menjelaskan bahwa usia dewasa madya, lebih memperhatikan dan peduli kepada keluarga. Tidak terkecuali pada kondisi keluarga yang memiliki pasien gangguan jiwa yang sedang dirawat di Instalasi Pelayanan Kesehatan Jiwa Terpadu. Keluarga dengan usia dewasa madya akan mendampingi atau menemani pasien gangguan jiwa selama perawatan 
$\begin{array}{llr}\text { berlangsung } & \text { dan hal } & \text { tersebut } \\ \text { dianggap } & \text { keluarga } & \text { sebagai } \\ \text { pengalaman } & \text { baru yang } & \text { dirasakan }\end{array}$

(Wicaksana, 2008).

Mayoritas responden yang mendampingi pasien gangguan jiwa di Instalasi Pelayanan Kesehatan Jiwa Terpadu adalah perempuan. Menurut Goleman (2000) perempuan cenderung lebih empati dan juga lebih dapat mengekspresikan emosionalnya daripada laki-laki. Dysvik \& Sommerseth (2010) menyatakan bahwa perempuan lebih memiliki kualitas merawat alami daripada lakilaki, selain itu perempuan juga lebih memiliki waktu dibandingkan lakilaki yang cenderung sibuk.

Hasil penelitian ini menunjukkan bahwa mayoritas responden mencapai pendidikan akhir pada tingkat sekolah dasar (SD). Semakin tinggi tingkat pendidikan seseorang (keluarga) maka akan sulit melakukan tugas perwalian atau mendampingi pasien gangguan jiwa. Hal tersebut dikarenakan tingkat pendidikan yang tinggi lebih banyak aktivitas dan waktu yang dibutuhkan lebih terjadwal dibandingkan dengan seseorang dengan tingkat pendidikan rendah.

Mayoritas responden memiliki penghasilan $\leq 1000000$ atau kurang dari UMR daerah tersebut. Penelitian Trani et al (2015) menyatakan bahwa seseorang pada keluarga dengan pendapatan rendah akan memperburuk dan menyebabkan penyakit mental. Berdasarkan pernyataan tersebut dapat menjelaskan bahwa keluarga yang mendominasi berpendapatan rendah karena rata-rata seseorang dengan gangguan jiwa berlatar belakang dari keluarga yang kurang berkecukupan atau berpenghasilan rendah. Keluarga yang mendampingi pun berpendapatan rendah karena beban yang diperoleh dari pekerjaan berbeda dengan seseorang dengan penghasilan tinggi.

Distribusi frekuensi responden berdasarkan hubungan dengan pasien menunjukkan bahwa, sebagian besar responden adalah orang tua dari pasien, dengan persentase $50 \%$. Keluarga merupakan unit asuhan keperawatan, masalah kesehatan yang timbul dalam keluarga akan 
mempengaruhi seluruh anggota keluarga. Masing-masing keluarga memiliki peranan tersendiri dalam menjalankan proses keluarga, namun peranan yang tampak jelas ketika ada anggota keluarga mengalami masalah kesehatan adalah orang tua. Berdasarkan hasil penelitian diketahui bahwa rata-rata skor kecemasan keluarga saat menunggu pasien gangguan jiwa menjalani rawat inap di Instalasi Pelayanan Kesehatan Jiwa Terpadu adalah 20. Skor tersebut apabila diklasifikasikan menurut skala HARS termasuk dalam kategori kecemasan sedang (18-24).

Penelitian yang dilakukan oleh Craske (2003) menjelaskan bahwa jenis kelamin mempengaruhi kecemasan. Selain itu, penelitian lain dilakukan oleh Suwondo, Sujarwo \& Supriyadi (2013) menyatakan bahwa faktor yang mempengaruhi kecemasan terdiri dari kekambuhan pasien, masalah ekonomi, dan tingkat pendidikan. Persepsi awal keluarga terhadap pasien gangguan jiwa beragam akibat kurangnya pemahaman terhadap gangguan jiwa. Keluarga beranggapan bahwa gangguan jiwa merupakan penyakit di luar medis. Penelitian Zafar et al., (2008) menemukan bahwa akibat adanya kesalahan persepsi keluarga terhadap penyakit gangguan jiwa, penanganan gangguan jiwa yang profesional terhambat. Kondisi yang berlarut-larut pada pasien gangguan jiwa tersebut dan menjadikan keluarga menjadi lebih cemas akan kesembuhan pasien yang dirawat di rumah sakit. Penelitian Ngadiran (2010) menyebutkan bahwa keluarga yang menunggu pasien gangguan jiwa menjalani perawatan akan memiliki beban psikologis dan beban finansial.

Beban psikologis yang dirasakan oleh keluarga muncul akibat adanya gejala psikotik (kekambuhan) pada pasien. Hasil penelitian Ngadiran (2010) juga menjelaskan bahwa kekambuhan pasien dapat menimbulkan permasalahan emosional pada keluarga pasien seperti perasaan cemas, sedih, malu terhadap orang lain, stres menghadapi gangguan perilaku dan frustasi akibat pola interaksi yang berubah.

Tidak jarang penanganan gangguan jiwa dirumah sakit menggunakan terapi-terapi yang beresiko tinggi seperti terapi ECT. Terapi tersebut 
menimbulkan kecemasan bagi keluarga yang mendampingi karena keluarga merasa sedih atau tidak tega dengan prosedur pengobatan tersebut. Namun setelah pasien mengalami perubahan yang signifikan, tingkat kecemasan menjadi menurun.

Beban finansial (masalah ekonomi) yang dialami keluarga ketika menemani pasien menjalani perawatan meliputi, transportasi yang jauh, hambatan dalam melaksanakan aktivitas, gangguan dalam kehidupan berumah tangga, dan biaya sehari-hari ketika menunggu pasien menjalani perawatan (Wardani, 2009).

Kondisi disaat pasien menjalani rawat inap mengakibatkan terganggunya peranan keluarga, dimana peran tersebut menggambarkan perilaku interpersonal, sifat, dan kegiatan keluarga. Seperti peranan ayah sebagai pencari nafkah, ibu sebagai pengurus rumah tangga, dan anak melaksanakan peranan psikososial sesuai dengan perkembangannya (Ali, 2010). Peneliti mengamati kecemasan keluarga selama melakukan penelitian berasal dari proses penyakit pasien yang panjang, kekambuhan yang diakibatkan ketidakpatuhan pasien selama proses perawatan, prosedur penanganan pasien selama di rumah sakit (terapi), dan beban ekonomi atau finansial.

Kecemasan Keluarga Pasien

Gangguan Jiwa Saat Pasien Menjelang Pulang dari Instalasi Pelayanan Kesehatan Jiwa Terpadu RSUD Banyumas

Hasil penelitian menjelaskan bahwa rata-rata skor kecemasan keluarga pasien gangguan jiwa saat pasien menjelang pulang dari Instalasi Pelayanan Kesehatan Jiwa Terpadu RSUD Banyumas adalah 15,18 atau berada pada klasifikasi kecemasan ringan $(<17)$. Pada penelitian ini kecemasan keluarga saat pasien gangguan jiwa menjelang pulang dari Instalasi Pelayanan Kesehatan Jiwa Terpadu berada pada tingkat rendah. Hal tersebut terjadi dikarenakan keluarga sudah cenderung siap menerima kepulangan pasien gangguan jiwa akibat informasi yang diterima dari pihak tenaga kesehatan. Hal tersebut sesuai dengan penelitian Huda (2012) bahwa keluarga memerlukan informasi dari tenaga kesehatan berupa sosialisasi mengenai penyakit pasien serta 
pengobatan lanjutan untuk bukan tanpa masalah kecemasan. Dari memberikan kesiapan kepada hasil penelitian keluarga memiliki keluarga ketika pasien kembali ke kecemasan walaupun pada tingkat masyarakat.

Hasil penelitian Mustaan \& Mudiari (2014) menunjukkan bahwa efek hospitalisasi bagi pasien gangguan jiwa sebagian besar menghasilkan efek hospitalisasi yang positif, sehingga keluarga mendapatkan kepuasan terhadap pelayanan kesehatan. Kepuasan terhadap pelayanan kesehatan ditunjukkan oleh sikap keluarga yang tidak terlalu khawatir setelah pasien menjalani perawatan dan kecemasan yang dirasakan keluarga dalam tingkat yang rendah. Rumah sakit sudah dianggap sebagai tempat penanganan gangguan jiwa yang baik. Keluarga mempercayai rumah sakit menjadi tempat penanganan masalah kesehatan anggota keluarganya yang efektif. Sehingga ketika pasien gangguan jiwa dalam masa perencanaan pulang, keluarga meyakini pasien sudah sehat akibat kepercayaan yang tinggi pada rumah sakit. Hal tersebut ditambah dengan pandangan keluarga mengenai definisi sehat yang terlalu dangkal. Perencanaan pemulangan pasien rendah. Kecemasan pada penelitian ini terletak pada adanya stigma dan diskriminasi pada keluarga pasien gangguan jiwa.

Perbedaan antara kecemasan keluarga pasien gangguan jiwa saat pasien menjalani rawat inap dan menjelang pulang dari Instalasi Pelayanan Kesehatan Jiwa Terpadu $\underline{\text { RSUD Banyumas }}$

Berdasarkan uji statistik dengan uji $\mathrm{t}$ berpasangan didapatkan $\mathrm{p}$ value sebesar 0,000 . Artinya ada perbedaan kecemasan keluarga pasien gangguan jiwa saat mendampingi rawat inap dengan kecemasan keluarga saat pasien gangguan jiwa menjelang pulang dari Instalasi Pelayanan Kesehatan Jiwa Terpadu RSUD Banyumas.Perbedaan kecemasan dipengaruhi oleh pemahaman keluarga, pengetahuan keluarga, dan beban keluarga. Pemahaman yang salah terkait gangguan jiwa dirasakan oleh berbagai keluarga pasien gangguan jiwa. Keluarga pasien mengungkap gangguan ini merupakan penyakit non-medis sehingga 
keluarga awalnya kurang percaya akan penanganan medis. Kondisi tersebut dikarenakan penanganan yang dilakukan keluarga memprioritaskan pada penanganan non-medis sebelum akhirnya menyerahkan pengobatan pada medis. Selama menjalani perawatan medis, keluarga melihat adanya perubahan yang cukup signifikan pada pasien.

Keluarga mulai mempercayai pelayanan profesional atau medis pada gangguan jiwa dibandingkan dengan penanganan non-medis diakibatkan oleh adanya penyesuaian diri terhadap lingkungan dan kondisi keluarga tersebut (adaptasi). Kepercayaan akan pelayanan tersebut secara tidak langsung mempengaruhi konsep sehat yang dianut oleh keluarga. Ketika pasien diputuskan oleh tenaga kesehatan dalam perencanaan pulang, keluarga tidak akan mengkhawatirkan pasien dan menganggap bahwa pasien telah sembuh.

Kondisi keluarga saat mendampingi pasien merupakan kondisi dimana keluarga belum mengetahui secara jelas keadaan pasien dan belum ada kepastian akan kesembuhan pasien. Sedangkan kondisi saat pasien dalam perencanaan pemulangan, keluarga sudah mendapatkan berbagai stimulus selama berada di Instalasi Pelayanan Kesehatan Jiwa Terpadu ditambah dengan adanya perencanaan pemulangan sebagai proses keperawatan dari tenaga kesehatan. Proses keperawatan meningkatkan respon adaptasi sehingga pada saat pasien dalam perencanaan pemulangan, keluarga mendapatkan pengetahuan yang jelas terkait keadaan pasien.

Penelitian ini menunjukkan bahwa keluarga pasien gangguan jiwa memiliki beban psikologis dalam bentuk kecemasan. Penelitian Ngadiran (2010) menjelaskan beban pada keluarga pasien gangguan jiwa ada dua yaitu beban psikologis dan beban finansial. Kondisi tersebut yang membuat kecemasan keluarga saat mendampingi pasien berbeda dengan saat pasien menjelang pulang. Hal tersebut dikarenakan saat pasien menjelang pulang keluarga sudah menganggap pasien sembuh atau kembali ke kondisi normal. Sementara untuk beban finansial 
keluarga perlu mengeluarkan biaya untuk transportasi dan biaya selama mendampingi pasien serta berdampak mengurangi pendapatan yang ada. Sedangkan setelah pasien mendapat perencanaan pulang, beban finansial keluarga menjadi berkurang.

Kecemasan keluarga saat mendampingi pasien gangguan jiwa menjalani perawatan lebih tinggi diakibatkan oleh adanya proses menyesuaikan diri atau adaptasi yang baik dari keluarga. Hal tersebut mengakibatkan adaptasi keluarga dengan lingkungan sudah matang dan kecemasan menjadi lebih rendah ketika pasien dalam perencanaan pemulangan. Dengan perubahan tersebut, keluarga harus mempertahankan integritas dirinya yaitu beradaptasi secara kontinu (Nursalam, 2008).

Perbedaan kecemasan keluarga dapat dilihat pula dengan melihat sifat dari masalah yang dihadapi pada kedua kondisi tersebut. Ketika keluarga mendampingi pasien menjalani rawat inap faktor penyebab kecemasan lebih nyata dirasakan oleh keluarga seperti adanya kekambuhan dan masalah ekonomi. Namun ketika pasien akan menjelang pulang, faktor penyebab kecemasan keluarga masih bersifat antisipasi. Seperti stigma dan diskriminasi yang mungkin terjadi bila pasien berada di lingkungan masyarakat nantinya.

\section{KESIMPULAN}

Terdapat perbedaan yang signifikan antara kecemasan keluarga saat mendampingi pasien gangguan jiwa menjalani rawat inap dan menjelang pasien pulang rawat inap dari Instalasi Pelayanan Kesehatan Jiwa Terpadu RSUD Banyumas dengan $\mathrm{p}$ value 0,000 . Kecemasan keluarga saat mendampingi pasien lebih besar daripada saat pasien menjelang pulang. 


\section{DAFTAR PUSTAKA}

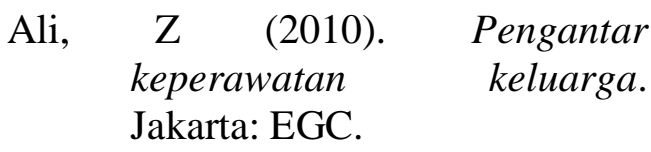

Amalia, L. (2009). Kesiapan keluarga menghadapi kepulangan pasien rawat inap gangguan jiwa (studi kasus pada keluarga pasien rawat inap gangguan jiwa di rumah sakit jiwa dr. amino gondhohutomo). Skripsi. Universitas Negeri Semarang. Retrieved from http://lib.unnes.ac.id/6562/

American Psychiatric Association. (2000). DSM-IV-TR. Diagnostic and Statistical Manual of Mental Disorders (4 ${ }^{\text {th }}$ Ed., Text Revision). Washington, DC: Author.

Andrade, C., Shah, N., Tharyan, P., Reddy, M. S., Thirunavukarasu, M., Kallivayalil, R. A., Mohandas, E. (2012). Position statement and guidelines on unmodified electroconvulsive therapy. Indian Journal of Psychiatry, 54(2), 119-133. doi:10.4103/0019-5545.99530

Craske, M. G. (2003). Origins of phobias and anxiety disorders: why more women than men?. Oxford: Elsevier.

Dahlan, M. S. (2010). Besar sampel dan cara pengambilan sampel dalam penelitian kedokteran dan kesehatan. Jakarta: Salemba Medika.
Ghanem, M., Gadallah, M., Meky, F. A., Mourad, S., \& El Kholy, G. (2009). National survey of Prevalence of Mental Disorders in Egypt: preliminary survey. Retrieved from http://apps.who.int//iris/handle $\underline{\text { /10665/117609 }}$

Goleman, D. (2000). Kecerdasan emosional. Jakarta: Gramedia Pustaka Utama.

Hellström, L., Eplov, L., Nordentoft, M., Ostergaard, S., \& Bech, P. (2014). The Diagnostic Apathia Scale predicts the ability to return to work following depression or anxiety. Acta Neuropsychiatrica, 1-8. doi:10.1017/neu.2014.23.

Huda, N. (2012). Tingkat Pemahaman Keluarga Terhadap Perencanaan Pemulangan Klien Gangguan Jiwa Yang Di Rawat Di Kelas I Dan Ip Rumah Sakit Jiwa Tampan Provinsi Riau.

Kessler, R. C., Demler, O., Frank, R. G., Olfson, M., Pincus, H. A., Walters, E. E., ... Zaslavsky, A. M. (2005). Prevalence and treatment of mental disorders, 1990 to 2003. New England Journal of Medicine, 352(24), 2515-2523. doi:10.1056/NEJMsa043266

Leske, J. S. (2002). Interventions to decrease family anxiety. Critical Care Nurse, 22(6), 61-65.

Mustaan, M., \& Mudiari, N. K. (2014). Pengaruh efek pasca 
hospitalisasi terhadap harga diri klien gangguan jiwa di Kecamatan Colomadu Kabupaten

Karanganyar. Jurnal Ilmu Keperawatan Indonesia, 6(3).

Ngadiran, A. (2010). Studi fenomenologi pengalaman keluarga tentang beban dan sumber dukungan keluarga dalam merawat klien dengan halusinasi. Retrieved from http://www.lib.ui.ac.id.

Nursalam. (2008). Konsep \& Metode Keperawatan (ed. 2). Jakarta: Salemba Medika.

Simanjuntak, I. T. M., \& Daulay, W. (2010). Hubungan pengetahuan keluarga dengan tingkat kecemasan dalam menghadapi anggota keluarga yang mengalami gangguan jiwa di rumah sakit jiwa propinsi Sumatera Utara, Medan. Retrieved from http://repository.usu.ac.id/han $\underline{\text { dle } / 123456789 / 21162}$

Suwondo,-; Sujarwo,-; Supriyadi,-. (2013). Hubungan antara frekuensi kekambuhan pasien skizofrenia dengan tingkat kecemasan pada keluarga. Jurnal Ilmu Keperawatan Dan Kebidanan, (Vol 1, No 4 (2013)). Retrieved from http://pmb.stikestelogorejo.ac. id/ejournal/index.php/ilmukep erawatan/article/view/196.

Trani, J.-F., Bakhshi, P., Kuhlberg, J., Narayanan, S. S., Venkataraman, H., Mishra, N. N., Deshpande, S. (2015). Mental illness, poverty and stigma in India: a case- control study. British Medical Journal Open, 5(2). http://doi.org/10.1136/bmjope n-2014-006355.

Wardani, I. Y. (2009). Pengalaman keluarga menghadapi ketidakpatuhan klien gangguan jiwa dalam mengikuti regimen terapeutik: pengobatan. Tesis. Universitas Indonesia, Jakarta.

Wicaksana, I. (2008). Mereka bilang aku sakit jiwa: Refleksi kasuskasus psikiatri dan problematika kesehatan jiwa di Indonesia. Yogyakarta: Kanisius.

Yosep, I. (2011).Keperawatan jiwa (Edisi Revisi). Bandung : Refika Aditama

Zafar, S. N., Syed, R., Tehseen, S., Gowani, S. A., Waqar, S., Zubair, A., ... Naqvi, $\mathrm{H}$. (2008). Perceptions about the cause of schizophrenia and the subsequent help seeking behavior in a Pakistani population - results of $a$ cross-sectional survey. BioMed Central Psychiatry, 8, 56. http://doi.org/10.1186/1471244X-8-56 